\title{
THE USES AND ABUSES OF "VULNERABILITY» IN EU ASYLUM AND REFUGEE PROTECTION: PROTECTING WOMEN OR REDUCING AUTONOMY?
}

\section{Los usos y abusos de la "vulnerabilidad» en el asilo de la UE y la protección de refugiados: ¿Proteger a las mujeres o reducir la autonomía?}

\author{
Jane Freedman \\ Université de Paris 8, CRESPPA-GTM (Francia)
}

\begin{abstract}
Keywords
Gender Vulnerability

Asylum

Europe

ABSTRACT: The concept of vulnerability has become central in European asylum and refugee law and policy in recent years. The adoption of special measures designed to offer greater protection to vulnerable asylum seekers might be seen as a positive step. However, the way in which vulnerability has been defined is open to question. Too often vulnerability is reduced to a simplistic and essentialised categorisation, which is also highly gendered and racialized. Women are thus categorized as "vulnerable» a priori, without real consideration of the structural and contextual causes of this vulnerability. Whilst being classed as "vulnerable" can increase chances of protection within EU asylum and refugee systems, the impacts on those who are classified as vulnerable can be felt as forms of symbolic violence which reduce agency and autonomy. Based on interviews with asylum seekers and refugees, as well as an analysis of recent EU asylum directives, this article calls for a re-thinking of the uses of vulnerability in EU asylum policies in order to afford better protection, whilst at the same time recognising the agency and autonomy of asylum seekers and refugees.
\end{abstract}

RESUMEN: El concepto de vulnerabilidad se ha convertido en el centro de la legislación y la política europeas de asilo y refugio en los últimos años. La adopción de medidas especiales diseñadas para ofrecer una mayor protección a los solicitantes de asilo vulnerables puede considerarse un paso positivo. Ahora bien, la forma en que se ha definido la vulnerabilidad es cuestionable. Con demasiada frecuencia, la vulnerabilidad se reduce a una categorización simplista y esencializada, que también es altamente generizada y racializada. Las mujeres son clasificadas como "vulnerables» a priori, sin una consideración real de las causas estructurales y contextuales de esta vulnerabilidad. Si bien ser clasificado como "vulnerable» puede aumentar las posibilidades de protección dentro de los sistemas de asilo y refugio de la UE, los impactos en quienes son clasificados como vulnerables pueden ser sentidos como

Palabras clave formas de violencia simbólica que reducen la agencia y la autonomía. En base a entrevistas con solicitantes de asilo y refugiados, así como en un análisis de las recientes directivas de

Género

Vulnerabilidad

Asilo asilo de la UE, este artículo propone repensar los usos de la vulnerabilidad en las políticas de asilo de la UE para proporcionar una mejor protección al tiempo que reconozcan la agencia Europa y la autonomía de los solicitantes de asilo y de los refugiados.

Correspondence to: Jane Freedman. Université de Paris 8, CRESPPA-GTM. 59 Rue Pouchet. 75017 Paris (France). Corrisponding author: jane.freedman@wanadoo. $\mathrm{fr}$ - http://orcid.org/0000-0003-2440-7131

How to cite: Freedman, Jane. (2018). «The uses and abuses of "vulnerability" in EU asylum and refugee protection: protecting women or reducing autonomy?»; Papeles del CEIC, vol. 2019/1, papel 204, 1-15. (http://dx.doi.org/10.1387/pceic.19525).

Received: March, 2018; Final version: October, 2018.

ISSN 1695-6494 / (c) 2019 UPV/EHU 
In the past few years, the category of "vulnerability " has taken a central role in European asylum and refugee legislation and policies. This has had a particular impact on the perceptions and treatment of women asylum seekers and refugees. The concept of vulnerability is often linked to gendered constructions and norms which portray women as intrinsically weaker and thus more physically exposed to danger than men, and thus more in need of protection. But although it might be seen as a positive move to greater protection for women that EU and Member State institutions are adopting policies which specify special measures for those judged to be vulnerable, many questions remain. Firstly, how should vulnerability be defined and identified in the case of asylum seekers and refugees? And what are the impacts of being defined as vulnerable for an asylum seeker or refugee? It might be argued that the use of the concept of vulnerability is just one more aspect of the "categorical fetishism" (Crawley and Skleparis, 2017) when dealing with refugees in Europe, in an attempt to divide those who are the "good" refugees worthy of support, from the "bad" migrants who are believed to be seeking to abuse the system to gain protection which they do not deserve. To be categorised as "vulnerable» and to gain access to the particular protections that this status bestows, asylum seekers and refugees have to conform to a certain number of criteria and have to behave and present themselves in specific ways, so as to be understood as those in need of and deserving extra protection. To do so may force them to act in ways that are contrary to their real self-perceptions and self-identifications, and in some cases, perhaps contrary to other interests. Being labelled as «vulnerable» can also act as an impediment to full autonomy and agency as the "vulnerable" person is reduced to a dependent or childlike status. As Gilson argues, being labelled as vulnerable can suggest dependency, weakness, susceptibility to harm, and violability (Gilson, 2016). This article will explore the use of the category of vulnerability in the protection of women asylum seekers and refugees in the European Union, assessing both the possible benefits of this labelling, but also its negative impacts on these women. We will also explore how women can seek to subvert the label of vulnerability and to use it to advance their own individual or collective migratory projects and strategies.

The article is based on research carried out in various European settings - primarily in Greece and in France-, between 2015 and 2018, including interviews with asylum seekers and refuge ${ }^{1}$, with NGOs and associations supporting refugees, and with representatives of various European and international organisations concerned with refugee support and protection and/or with border control and immigration policies ${ }^{2}$. I spent time both on the Greek island of Kos where refugees were arriving and in Athens. In both locations I was able to observe the conditions of reception for refugees, and their interactions with various institutional actors, and NGOs, as well as carrying out interviews with refugees themselves. These interviews were carried out either in English, or with an interpreter. During the interviews the women I spoke to described their experiences of forced migration, the journeys they had undertaken, their reception conditions and interactions with authorities, NGOs and local populations. I

1 In total I carried out 45 interviews with women refugees in Greece and France. All interviews have been quoted anonymously to respect ethical requirement and protect the identity of interviewees.

2 Including UNHCR, European Parliament, Frontex, European Asylum Service, Greek Asylum Service, Médecins du Monde, Médecins sans Frontières, La Cimade, A total of 18 key informant interviews were carried out. 
also carried out observation and interviews in the various refugee camps in the Calais region in France where I was again able to observe living conditions of refugees and interactions with various actors, as well as speaking to refugee women about their experiences. Interviews with EU and international organisations were carried out either in person, or in certain instances by telephone or skype.

I will begin the article with an examination of the conditions which render asylum seeking and refugee women vulnerable, before moving on to examine how the notion of vulnerability has been integrated into EU policies in this area. In the second half of the article I examine the impacts of the labelling as vulnerable on women themselves, and on ways in which they can strategically use this label to support their own agency and autonomous projects.

One of the paradoxes of the emergence of the notion of vulnerability in EU asylum and refuge policies in recent years is the fact that many of the vulnerabilities of the people attempting to reach the EU to claim refugee protection have been created, or at least exacerbated, by EU policies themselves. The question of vulnerability of refugees, and of the specific vulnerabilities of certain groups of refugees, has become particularly acute in Europe since the start of what has been called the refugee "crisis" from 2014 onwards (Gilbert, 2015). The arrival, or attempted arrival of millions of people seeking refugee protection in Europe has led to rising numbers of deaths at sea and at EU borders, and a worsening humanitarian situation for many refugees who find themselves living in precarious, dangerous and insalubrious conditions. The securitisation of migration, and continuing attempts by the EU to close borders and prevent the arrival of refugees has not stopped the flows of people but has pushed them into taking increasingly expensive and risky routes to try to arrive in Europe to seek protection (Andersson, 2016).

Increasing insecurities for refugees have not affected all equally. Whilst violence is a constantly present element of the refugee journey, women face heightened risks of sexual and gender-based forms of violence. The interconnections between gender, migration, violence and insecurity have been highlighted by research in various regions of the world (Marchand, 2008; Freedman, 2012; Freedman, Kivilcim and Ozgur Baklacioglu, 2017). Different push and pull factors, migration control regimes, as well as social and economic conditions in countries of origin, transit and destination create varying types of insecurity and violence for men and women, depending on their varying social and economic positions and the relations of power between them. As Marchand argues: "lt goes without saying that the migration-violence nexus is gendered. Men and women are affected in different ways and the violence to which they are exposed is related to their position with respect to the migration-violence nexus." (2008: 1387). Recent research has also highlighted the physical risks of border crossing for women, and the higher rate of mortality at the borders for women than for men (Pickering and Cochrane, 2012). Despite these risks, however, refugee women continue to try to reach Europe desperate to escape conflict, violence and persecution in their home countries and to find a safer home for them and their families.

In 2015 over one million people arrived in the EU seeking refugee protection, and thousands died on the route. Since then the numbers of arrivals have diminished somewhat but there 
are still many thousands of people who attempt the increasingly dangerous journey every day. There are still no accurate statistics on the number of women amongst these refugees, and a persistent problem is the tendency to provide statistics which group "women and children» together, a categorisation which has been criticised by feminists for many years (Enloe, 1990) as it reduced women to the status of children, taking away their adult independence and autonomy. Statistics that are available show that women make up around $20 \%$ of the refugees arriving in Europe by boat ${ }^{3}$. Increasing numbers of women are also arriving alone, or with only their children, without any male partner or companion (Freedman, 2016). Many of these women are fleeing gender-based forms of violence or persecution in their countries of origin, and they are also particularly vulnerable to gendered violence on their journeys to and arrival in Europe. Their vulnerability to violence is not intrinsic to their status as women, but created by the conditions of migration and exacerbated by EU policies. The closing of many borders on the so-called Balkan route and the EU-Turkey Agreement of March $2016^{4}$ have further restricted refugees' possibilities of reaching the EU and have forced them to take even more dangerous and difficult routes (Lovertt, Whelan and Rendon, 2017). Women I spoke to talked about their insecurities and the danger of violence from many sources including border guards and police, smugglers, other refugees, and also members of their own families. One woman had walked across the mountainous border from Iran to Turkey carrying her three-year-old child. She described the terror of falling and being left to die by the smugglers, or of being apprehended by the Turkish border guards, "and you know what they do when they catch a woman who is alone» ${ }^{5}$. Other women talked about their fears during the boat crossing from Turkey to Greece: «I thought I was going to die, it was the worst experience ${ }^{6}$. The dangers of the journey exist for all refugees, but for women, the threat of sexual violence is added to that of the physical danger. Smugglers, for example, may subject women to rape and sexual harassment, and as women often have very few economic resources to pay the smugglers, they may instead demand sexual relations in payment for the journey.

Many humanitarian and aid organisations deal with the refugees as "family" groups and assume that the men will protect the women with whom they are travelling. As well as obscuring relations of domination and violence within these groups, this also acts to silence the voice of women, and to take away the possibilities for them to express their own needs and wishes. The insecurities faced by women on the journey mean that many of them may choose to find a group of other refugees, or a man, with whom they can travel. So, in fact, many of the "family" groups arriving are not families at all in the strict "biological» sense of the word. And even when they are "real» family groups, dealing only with the male "head" of the family, means that many forms of exploitation, violence or domination may be ignored.

Migration can also lead to changes in relations of power and gender relations within families and couples, and in some cases to increasing incidences of domestic violence. As pointed out above, the known dangers and risks of the refugee journey mean that many women choose to travel in a "family" group with men that they may not have known previously. This forma-

\footnotetext{
See: http://data2.unhcr.org/en/situations/mediterranean. Last visit: 11/10/2018.

See: http://europa.eu/rapid/press-release_MEMO-16-963_fr.htm. Last visit: 11/10/2018.

Interview, October 2017.

Interview, July 2015.
} 
tion of "family» groups may offer protection to some women but may also lead to varying forms of violence and exploitation within the groups, which are overlooked by those outside who assume that men will protect women travelling with them. Violence occurs also within "real» families. Médicins Sans Frontières (MSF), for example, has reported cases of both psychological and physical violence within families, and women have spoken about the fact that they were victims of violence from their husbands during their journeys. These women suffered both the insecurities of their journey, and from their own husbands, who not only did not protect them, but also offered a threat. Women in this situation find it almost impossible to leave their abusive husbands or partners because the idea of continuing the journey alone, or just with their children, is too difficult. So, they find themselves stuck in a violent relationship. There have also been reports that women who have arrived in an EU country have had little help or support in escaping violence from their husbands or partners. One report in Germany, for example, recounted the story of a Syrian woman whose husband raped and beat her whilst they were living in a temporary camp set up to house newly arrived refugees. When the woman tried to file a complaint with the police they would not listen to her, and there was no real help either from social work or refugee support services. A group founded to help refugee women in Berlin explained that: "There is no real security for asylum-seeking women because whenever they are attacked, either physically or sexually harassed, nobody knows what to do. There is no clear policy»"

In addition, women who do reach the EU and who wish to make an asylum application on the grounds of gender-based violence or persecution face significant barriers in the refugee status determination process. There is still evidence that women's asylum claims face significant barriers both in terms of the interpretation of the Convention and in terms of the procedural difficulties. One of the major issues is the fact that women's claims are often not considered "credible», and they have more difficulty in providing material proof of these claims (Singer, 2014). Further difficulties arise from the fact that women may still be interviewed together with their husbands or children which may prevent them from telling their own stories, and although it is recommended that a same sex interviewer should be provided this is not always the case. For women who have been victims of sexual or genderbased violence, the fact of recounting the detail of their experience to an interviewer of the opposite sex can prove a significant barrier. In terms of the interpretation of the Convention, women's claims which are based on gendered forms of persecution are often considered under the grounds of their belonging to a "particular social group». However, there is still not a real agreement about what constitutes a "particular social group" and how this Convention ground can be properly applied to claims based on gender-related forms of persecution.

There is thus a real case for arguing that refugees' vulnerabilities are highly gendered, but this acknowledgement should not mean that all women asylum seekers and refugees are categorised a priori as "vulnerable», as we will discuss further below.

7 Cited in Moore, J. (2015), 'When you're a refugee and your husband beats you, you're basically on your own', Buzzfeed, 29 October 2015. Available at: https://www.buzzfeednews.com/article/jinamoore/when-youre-arefugee-and-your-husband-beats-you-youre-basica. Last visit: 11/10/2018 


\section{INTEGRATING THE RECOGNITION OF VULNERABILITY INTO EUROPEAN ASYLUM AND REFUGEE POLICIES}

In the previous section the existence of real sources of vulnerability and insecurity for women asylum seekers and refugees has been shown. But what policy response has there been to the risks of violence and the specific insecurities faced by women asylum seekers and refugees? The 1951 Convention on the Status of Refugees, the major international convention on which international and national refugee policy and law are based, does not mention the notion of vulnerability, or make reference to the specific situation of some groups of refugees who may be more vulnerable than others. Neither does the Convention have any mention of sex or gender, or of the specific needs or vulnerabilities of refugee women (Freedman, 2015). However, the United Nations High Commission for Refugees (UNHCR) has issued various sets of guidelines concerning specific groups of refugees distinguished by gender, age or disability, and recommend special treatment for these groups in relation to their particular vulnerabilities. In reaction to widespread critique from feminist groups at the lack of specific guidance on protection for women asylum seekers and refugees, for example, UNHCR has issued various guidelines on the protection of women, victims of sexual violence, or victims of trafficking (UNHCR, 1991, 1995, 2003 and 2006). These guidelines integrate an assumed notion of vulnerability of these particular groups and their need for added protection in the face of this vulnerability. But "group vulnerability reasoning carries pitfalls with it, most notably essentialism, stigmatization, and paternalism» (Peroni and Timmer, 2013: 1085). As Fineman argues, the equation of vulnerability with certain group identities supports the liberal myth that "normally" people are self-sufficient and autonomous (Fineman, 2008). This myth in turn legitimizes inequality and unequal treatment of different groups. Further, the criteria used by the UNHCR for selecting refugees for resettlement to third countries, rely almost entirely on the notion of vulnerability, so that any refugee who wishes to be a candidate for resettlement needs to prove that they are indeed vulnerable to hope to gain a place on the list. Gender again plays a major role in this notion of vulnerability, with one UNHCR official I spoke to expressing the idea that women should always be a priority for refugee resettlement, and that further, he believed that the UNHCR should in some circumstances choose to resettle only women ${ }^{8}$.

The integration of the notion of "vulnerability" has also become more central in EU asylum and refugee policies (Peroni and Timmer, 2013), again partly as a response to criticisms that issues of gender, and the specific situations of asylum seeking and refugee women and girls were not being taken into account in these policies (Freedman, 2015). The re-cast asylum directives which form part of the Common European Asylum System (CEAS), thus address the need for special procedural guarantees and for adapted reception conditions for those considered to be vulnerable. The re-cast Qualifications Directive adopted in 2011 obliges EU Member States to take into account the «specific situation of vulnerable persons such as victims of human trafficking (...) and persons who have been subjected to rape or other serious forms of psychological, physical or sexual violence ${ }^{9}$. The Reception Conditions Directive also

\footnotetext{
Interview, November 2017.

9 DIRECTIVE 2011/95/EU OF THE EUROPEAN PARLIAMENT AND OF THE COUNCIL of 13 December 2011 on standards for the qualification of third-country nationals or stateless persons as beneficiaries of international protection, for a uniform status for refugees or for persons eligible for subsidiary protection, and for the content of the protection granted (recast), available at: https://eur-lex.europa.eu/LexUriServ/LexUriServ.do?uri=OJ:L:2 011:337:0009:0026:EN:PDF. Last visit 14/10/2018.
} 
refers to the needs of vulnerable persons including "minors, unaccompanied minors, disabled people, elderly people, pregnant women, single parents with minor children, victims of human trafficking, persons with serious illnesses, persons with mental disorders and persons who have been subjected to torture, rape or other serious forms of psychological, physical or sexual violence, such as victims of female genital mutilation», and states that these people may have "special reception needs" ${ }^{10}$, Member States are required under these directives to take measures to identify those who fall into the category of vulnerability so that they can respond to their specific needs.

The recognition of vulnerability amongst asylum seekers and refugees, should in theory also be supported by the European Asylum Support Office (EASO) whose 2017-2019 objectives include a commitment to "contribute to the better identification of and adequate support to vulnerable applicants in asylum processes" ${ }^{11}$. Their website provides a "tool» for identifying persons with what they term "special needs», and they provide training for asylum officers across Europe for this process of identification.

But whilst the integration of the notion of "vulnerability" into the EU asylum system might be welcomed in that it acknowledges the increased risks and dangers faced by some asylum seekers and refugees, there is also a danger that this adoption of categories of "vulnerability" will lead to essentialisation and reification of categories, and to a failure to understand or taken into account the agency of those seeking asylum. As the European Council on Refugees and Exiles argues: "While specific safeguards in the asylum procedure and reception structures are certainly needed and welcomed, the legal 'vulnerabilisation' of applicants for international protection should not presume - nor be conflated with- a lack of agency of asylum applicants and refugees» (ECRE, 2017: 13).

\section{IDENTIFYING WHO IS «VULNERABLE»}

Inherent in the adoption of measures of protection for vulnerable asylum seekers and refugees, is the assumption that there will be measures in place to identify who is "vulnerable", and that vulnerability is something that can be identified in an individual. This assumption, however, is not unproblematic, relying as it does on a belief that vulnerability is a characteristic which is easily identifiable and objectifiable in an individual. But beyond the most visible signs of "vulnerability" such as pregnancy or physical handicap, how can more hidden or invisible forms of vulnerability such as mental illness and post-traumatic stress, among others, be identified? This question is even more acute in situations such as those in many European States where there is a lack of personnel working on this identification of vulnerability. The integration of the idea of protecting vulnerable persons in EU asylum and refugee policies has led to the establishment of various systems for identifying this vulnerability. In the "hotspots» on the Greek islands, for example, the process of identifying

10 DIRECTIVE 2013/33/EU OF THE EUROPEAN PARLIAMENT AND OF THE COUNCIL of 26 June 2013 laying down standards for the reception of applicants for international protection (recast). Available at: https://eur-lex. europa.eu/legal-content/EN/TXT/PDF/?uri=CELEX:32013L0033\&from=FR. Last visit 14/10/2018.

11 EASO, Multiannual programming 2017-2019, December 2016, available at: http://bit.ly/2miey0z. Last visit: $14 / 10 / 2018$. 
vulnerable refugees is critical. Since the EU-Turkey Agreement of March 2016, only those who are formally identified as vulnerable will be allowed to move from the islands on to the Greek mainland to have their asylum claim heard. The label of vulnerability is thus hugely valuable in allowing an individual to escape from the geographical restriction and retention imposed on others, and to benefit from the better reception conditions on the Greek mainland (even if these conditions are themselves not always optimal). The system put in place for identifying those who are vulnerable has been heavily criticised however. A lack of staff carrying out these assessments mean that there is a long waiting list for interviews to determine vulnerability. And even when an interview takes place, it might often be carried out in a hurried and superficial manner, which does not allow a real understanding of the situation of the person concerned, and the ways in which they may be vulnerable beyond an obvious physical state such as physical handicap or pregnancy. A report published in 2017 found that: "the lack of sufficient medical staff, the lack of medical expertise among the staff, and the format of the assessments, which interviewees described as taking only a few minutes, result in many people's conditions not being identified. This is particularly the case for vulnerabilities that are less apparent - mental health conditions, experiences of torture or of sexual or gender-based violence- where a brief meeting, without a relationship of trust having been established, can result in people not disclosing such conditions» (Refugees International, 2017).

In other countries, such as France and the UK, a questionnaire is used to determine whether or not an asylum seeker should be classed as «vulnerable». Again, these questionnaires rely on a "listing" of different categories of potential vulnerability, including various forms of physical handicap, or being pregnant. Asylum seekers may also request a medical visit to demonstrate that they are vulnerable. Here as well, any more complex idea of vulnerability as not a physical or intrinsic quality, but a contingent, contextual and multi-layered construction is missing.

The types of vulnerability assessments set up in Europe thus tend to emphasise visible physical dependency or weakness and neglect more complex relational and contextual causes and forms of vulnerability, simplifying and treating vulnerability as one dimensional rather than as a "layered concept» (Luna, 2009). And as Clark (2007) has previously argued, this type of vulnerability assessment may mean that refugees feel obliged to co-operate with or appropriate ascribed characteristics of vulnerability in order to invoke compassion or to gain access to rights which would otherwise be denied them. In some cases, as we will discuss below, this may even extend to becoming pregnant as a deliberate strategy for being categorised as vulnerable. But the need to conform to these rather essentialising notions of what vulnerability looks like can also reinforce pre-existing dichotomies and stereotypes of victimhood and menace. Stereotypes, which as we will discuss below, are intimately linked to gendered and racialized social constructions.

\section{VULNERABILITY, THREAT AND GENDER: REINFORCING ESSENTIALIST DICHOTOMIES?}

Whilst the integration of the category of vulnerability into EU asylum and refugee policies may be seen as a way to afford greater protection to women who are particularly at risk of 
gender-based violence or other gendered forms of discrimination and persecution, it could also be seen to be reinforcing already existing essentialist and gendered representations. Hollander (2001), suggests that widely shared understandings and representations of gender associate femininity with vulnerability and masculinity with dangerousness. She also points out that gendered understandings of vulnerability and dangerousness cannot be understood in isolation from other hierarchies of power and domination such as race, class, age etc. This assertion seems to be supported in an analysis of representations of asylum seekers and refugees arriving in the European Union. This analysis shows that the representations of the current influx of refugees in the media and in political discourse are highly gendered. For men, and particularly young men, there is a persistent representation of the threat that they pose to Europe (Allsopp, 2017; Herz, 2018). The fact that some of those involved in the Bataclan attacks in Paris in November 2015 may have travelled through Turkey and Greece with the other refugees added fuel to these representations of threat, as did the supposed involvement of some refugees in the sexual violence perpetrated against women in Cologne during the 2016 New Year celebrations. Following the Cologne attacks there were many articles in the media and statements by political leaders drawing on discourses of the lack of respect for women's rights in "other" cultures, and the need to "educate» refugees on "European values» concerning women's rights and gender equality.

Women, on the other hand, when they are made visible in discourses on refugees, are portrayed largely as vulnerable, as victims and in need of protection. And these representations are reinforced by UNHCR and EU policies. As previous research has shown, refugee women are more often than not portrayed as "passive subjects in need of humanitarian protection" (Olivius, 2016: 282). As such, they may be denied a "voice" and an opportunity to assert their agency in managing their migratory projects and journeys. These representations clearly have an impact on the experiences of women asylum seekers and refugees and the way that they are treated by both officials and others once they reach Europe. Women I interviewed, whilst highlighting the insecurity they felt, and the lack of support which they were receiving from European authorities, also claimed that they often felt diminished because of a lack of respect from the officials or from aid workers or members of the general public with whom they came into contact. Although being treated as "vulnerable» may be seen as an advantage, it also reduces women to what they feel is an «inferior" status where their own autonomous strategies and projects are undermined.

The intersections of gendered and racialized representations are also very pertinent here. The impacts of representations of vulnerability and victimhood were felt extremely keenly by Muslim women and this was particularly marked in the case of women who were wearing a hijab/headscarf who felt that they were treated as "other" and less educated, enlightened or intelligent than both European women and refugee men. One woman told me: "They think that all Syrian women are stupid and oppressed. They don't understand how it was for us before in Syria». This woman was a 30-year-old architect who had had a well-respected career before the outbreak of the war in Syria. She was single and had travelled alone to Europe, clearly demonstrating her autonomy and agency in the management of her journey and choice of a European country in which to seek protection. On arrival in France she had claimed asylum and had sought financial and material support from the relevant authorities. But as she told me, she felt that she was treated just as an "oppressed victim» by those working with refugees, even though in some cases the efforts to help her may have been well-intentioned. "The male refugees I know were not treated in the same way as me. They were 
given a lot more respect ${ }^{12}$, she affirmed. This feeling of being treated as someone without autonomy, an object of pity of charity was echoed by another Syrian woman interviewed in Paris who explained how she had been treated by the Croix Rouge Charity when she went to ask for food. "They gave me $1 \mathrm{~kg}$ of chocolate biscuits, and I told them I don't like chocolate. But then they said "I thought you said you were hungry. If you're hungry you'll eat them». I felt so humiliated. They just treated me as if I was stupid ${ }^{13}$. This type of symbolic violence seems unfortunately to be a common experience of women refugees arriving in Europe, and particularly those who are easily identified as Muslim. Even well-meaning charitable or humanitarian interventions tend to classify them as vulnerable victims, objects of pity, targeted for interventions in ways that foreclose their agency (Kallius, Monterescu and Rajaram, 2016). These representations of women (and particularly Muslim women), as «vulnerable» or "victims" devoid of agency, combine a racialized and gendered discourse which reduced their ability to express and make heard their own needs, wishes and opinions.

\section{THE STRATEGIC USES OF VULNERABILITY}

Being categorised as vulnerable can be seen as a form of "symbolic violence» by refugee women and can impact on their autonomy and agency. But, women can also strategically use their perceived vulnerability to gain some advantages in terms of migratory strategies and projects, thus demonstrating their agency and autonomy. Some women refugees, well aware of the label of vulnerability which is attached to them, have been able to make strategic use of this labelling to gain advantages for themselves and sometimes their families. This is the case of women who have chosen to travel alone to Europe whilst leaving their families behind in their countries of origin, or in a country of transit. They understand that as women travelling alone, they will be categorised as vulnerable by European authorities, and may thus find it easier to cross borders and to reach a country of destination and gain refugee protection. Once this protection has been gained for them, they can then seek to bring their family members to join them in Europe. Interviewees from various NGOs working with refugees in Greece, as well as from the UNHCR noted that this strategy was one of the explanations they had for the increase in the arrival of single women since 2014. These women, they argued, had taken a conscious decision to leave their families and to travel alone, despite the risks that this could entail, because they believed that as lone women, they would have a much better chance of reaching an EU country and of gaining refugee status. One Iraqi woman I interviewed in France had left her husband and travelled alone. She explained:

"I think that when you are a woman, it is dangerous, but also it might be easier for the border guards, the police to help you. It is easier for a woman to cross the borders, to get a place to stay. Because they are worried about you being on your own and being a woman..114

Some women may also use the fact of being pregnant to help them to advance their migration and to gain protection. Being pregnant is one of the most visible signs of "vulnerability»,

\footnotetext{
2 Interview, January 2016.

3 Interview, December 2015.

14 Interview, November 2015.
} 
and one which is thus easy to demonstrate to immigration officials or police. Some EU policy makers have suggested that women deliberately get pregnant on the journey to Europe in order to gain access and protection more easily. The situation is clearly more complex than this, with women becoming pregnant for many and varied reasons, including rape, lack of access to contraception, or a wish to have a child in a relationship which they have constructed during their exile. However, in some cases, it is clearly in these women's strategic interests to become pregnant. One NGO working in Greece with women who are caught up in a family reunification process, told me that it clearly is an advantage for women to be pregnant as this will lead to their claim being processed more quickly, and in many cases more favourably. Whilst the NGO worker I spoke to did not actively encourage women to become pregnant, she told me that she was always happy for them when they did so, because it was a real support to their case to be classified as "vulnerable» in this way ${ }^{15}$.

The perception of women as vulnerable, and the belief that they will access protection and help more easily is also used by the smugglers and those arranging journeys. Refugees told me that during the sea crossing from Turkey to Greece, for example, women were placed at the front and on the outside edges of the crowd of refugees in each boat. This was a deliberate strategy to ensure that the boat was more likely to be rescued by coastguards as they would be more inclined to help these vulnerable women, and far less likely to leave the boat to sink if they saw women on board.

Women refugees also show agency and autonomy through collective action, coming together to give mutual support and to help each other overcome the insecurities of the journey and of their status. In Athens, where many refugees are stuck in limbo, waiting to try and continue their onward journey to another EU Member State, or else awaiting the decision on their asylum application, women's squats and centres set up by migrant and refugee women provides a good example of women's agency and collective action to work together to respond to their shared insecurities and vulnerabilities.

One such "woman friendly» centre, organised by the Melissa Network, provides an example of good practice of a centre run by women for women, and which gives refugee women the opportunity to get support on a number of issues, such as health, parenting, legal advice, as well as learning Greek and engaging in cultural and art projects. The women who are able to benefit from this space clearly appreciated the support and feeling of community and safety that it provided them in their otherwise very insecure circumstances. Many of the women interviewed there said that it was the only place in Greece where they felt "at homen, and where they were able to get access to the information and resources they needed to survive. Women felt that here they were treated as "human", and not merely as "victims", objects of pity or of fear. Further, they found that the women only space encouraged them to be able to speak for themselves, organise and express agency as they could not do in more mixed environments. As one young Afghan woman explained: «Melissa is the first place I have found that is only for women. I feel comfortable here. We need more spaces that are for women only. Sometimes when you are mixed with the men and boys they are aggressive, and we can't say anything» ${ }^{16}$.

In France, women shared similar experiences of collective mobilisation to share information and support each other. A group of Syrian women refugees meets regularly at the Maison des

15 Interview, November 2017.
16 Interview, November 2017. 
Femmes in Paris. These women have been recognised as refugees, and so have a legal status in France, but have difficulties in accessing housing, education, childcare and other services. Many of them feel that they are in a vulnerable situation, but that this vulnerability is not recognised in any constructive way by French authorities or NGOs. "They say they want to help us. But they don't understand our situation and they don't listen to what we really need ${ }^{17}$. The women felt that by coming together they could listen to each other and help to support each other's projects. In this case, as in that of their Greek counterparts, they knew that they could not change public policy or legislation, but their collective action helped them to overcome the restricted and stereotyped categorisations to which they had been subject, and to rediscover autonomy and agency with the support of others. This type of mobilisation is an intervention which demonstrates how vulnerabilities can be remediated not only through "helping" a subject, but by fostering autonomy and promoting the development of capabilities of those who are vulnerable in a "nonpaternalistic» way. As Mackenzie argues: «Nonpaternalistic forms of protection recognize vulnerable persons or social groups as equal citizens, but as citizens who may need targeted forms of assistance to convert resources into functionings» (2014: 55).

\section{CONCLUSION}

It might be argued that the new focus on vulnerability, and the obligation placed on EU Member States to identify "vulnerable» asylum seekers and refugees in order to give them access to special procedures and special protection is a benefit for the many women who have been victims or who are at risk of violence (and, in particular, sexual and gender-based violence). However, the categorisation of women as vulnerable can also be experienced by these women as a form of symbolic violence and a limitation on their autonomy and agency. Women asylum seekers and refugees are not merely vulnerable victims, as many accounts of their agency and resilience have previously shown (Hunt, 2008). The women interviewed for this research all demonstrated clearly that they had strategies for migration and for seeking protection for both themselves and their families, strategies which also involved the tactical subversion or utilisation of the category of "vulnerability". Should we then argue for the abandon of this use of the category of vulnerable in relation to asylum seekers and refugees? I would argue that the category of vulnerability should not be rejected outright, as it is clear that in some circumstances women asylum seekers and refugees are at risk of specific gendered forms of violence, persecution and discrimination, and that they should in these circumstances be offered protection to counter these risks and to meet their needs. However, the current use of the category of vulnerability, both in the way that it is enshrined in policy and legislation, and in the way that these policies are applied, carried a real risk of essentialisation of women as vulnerable victims (and on the contrary of a denial of men's possible vulnerability as they are perceived only as a threat or danger). So perhaps the answer is to pursue a definition and an utilisation of the category of vulnerability that fully acknowledges the contextual and relational nature of being vulnerable, and which recognises that anyone, whatever their identity or status, may at sometimes be rendered vulnerable.

17 Interview, January 2016. 
Placing more emphasis on the fact that particular contexts create vulnerabilities, rather than a blanket labelling of certain predefined and essentialised categories of individuals as vulnerable, should also involve giving more voice and agency to these individuals, to define what their needs are and how their strategies of resilience can be supported. Asylum seekers and refugees, both women and men, need to be recognised as actors who have their own strategies and are capable of making choices (Moritz, 2012). And a part of this recognition and re-definition must be an acknowledgement that it is EU asylum and immigration policies that act to create and reinforce contextual vulnerabilities, and a reconsideration of the securitised border regimes which are at the core of this creation of vulnerability. In her account of vulnerability and feminist politics, Ziarek (2013) argues that to move beyond a dichotomy between vulnerability and resilience, we need to also understand the ways in which vulnerability can create space for political action. In doing so, we can move beyond the dominant biopolitical discourses on risk management replace the "ethos of security with intersubjective engagement" (ibidem: 82). This intersubjective engagement with refugees would allow them to emerge from the status of "speechless emissaries" (Malkki, 1996), and allow them to emerge as political subjects capable of agency; an agency which would go beyond strategies of manipulating the categories of vulnerability into which they have been placed. A feminist approach might thus argue for moving beyond the categories and meanings of "vulnerability" imposed by contemporary political and humanitarian framing of the refugee "crisis", and of moving towards a real engagement with women and men who are seeking international protection, to create an intersubjective understanding of both their capacities and needs.

\section{REFERENCES}

Allsopp, J. (2017). Aggressor, Victim, Soldier, Dad: Intersecting Masculinities in the European 'Refugee Crisis'. In J. Freedman, Z. Kivilcim and N. Ozgur Baklacioglu (Eds.). A Gendered Approach to the Syrian Refugee Crisis (pp. 155-175). London: Routledge.

Andersson, R. (2016). Europe's failed "fight» against irregular migration: ethnographic notes on a counterproductive industry. Journal of Ethnic and Migration Studies, 42(7), 10551075.

Clark, C. (2007). Understanding vulnerability: from categories to experiences of Congolese young people in Uganda. Children and Society, 21(4), 284-296.

Crawley, H., and Skleparis, D. (2017). Refugees, migrants, neither, both: categorical fetishism and the politics of bounding in Europe's 'migration crisis'. Journal of Ethnic and Migration Studies, 44(1), 48-64.

ECRE (2017). The Concept of Vulnerability in European Asylum Procedures. Brussels: ECRE.

Enloe, C. (1990). Bananas, Beaches, Bases: Making Feminist Sense of International Politics. California: University of Berkeley Press.

Fineman, M. A. (2008). The Vulnerable Subject: Anchoring Equality in the Human Condition. Yale Journal of Law and Feminism, 20(1). Available at: https://digitalcommons.law.yale. edu/yjlf/vol20/iss1/2. Last visit 14/10/2018. 
Freedman, J. (2012). Analysing the Gendered Insecurities of Migration: A Case Study of Female Sub-Saharan African Migrants in Morocco. International Feminist Journal of Politics, 14(1) 36-55.

Freedman, J. (2015). Gendering the International Asylum and Refugee Debate. Basingstoke: Palgrave Macmillan.

Freedman, J. (2016). Engendering Security at the Borders of Europe: Women Migrants and the Mediterranean 'Crisis'. Journal of Refugee Studies, 29(4), 568-582.

Freedman, J., Kivilcim, Z., and Ozgur Baklacioglu, N. (2017). A Gendered Approach to the Syrian Refugee Crisis. London: Routledge.

Gilbert, G. (2015). Why Europe Does Not Have a Refugee Crisis. Journal of Refugee Law, 27(4), 531-535.

Gilson, E. C. (2016). Vulnerability and Victimization: Rethinking Key Concepts in Feminist Discourses on Sexual Violence. Signs : Journal of Women in Culture and Society, 42(1), 71-98.

Herz, M. (2018). Becoming a possible threat: masculinity, culture and questioning among unaccompanied young men in Sweden. Identities, DOI:10.1080/1070289X.2018.1441692

Hollander, J. (2001). Vulnerability and Dangerousness: The Construction of Gender through Conversation about Violence. Gender and Society, 15(1), 83-109.

Hunt, L. (2008). Women asylum seekers and refugees: opportunities, constraints and the role of agency. Social Policy and Society, 7(3), 281-292.

Kallius, A., Monterescu, D., and Rajaram, P. K. (2016). Immobilizing Mobility: Border ethnography, illiberal democracy, and the politics of the "refugee crisis» in Hungary. American Ethnologist, 43(1), 1-13.

Lovertt, A., Whelan, C., and Rendon, R. (2017). The Reality of the EU-Turkey Statement: How Greece has become a testing ground for policies that erode protection for refugees. Oxford: Oxfam.

Luna, F. (2009). Elucidating the concept of vulnerability: layers not labels. International Journal of Feminist Approaches to Bioethics, 2(1), 121-139.

Mackenzie, C. (2014). The Importance of Relational Autonomy and Capabilities for an Ethics of Vulnerability. In C. Mackenzie, W. Rogers and S. Dodds (Eds). Vulnerability: New Essays in Ethics and Feminist Philosophy (pp. 33-60). Oxford: Oxford University Press.

Marchand, M. (2008). The Violence of Development and the Migration/Insecurities Nexus: Labour Migration in a North American Context. Third World Quarterly, 29(7), 1375-1388.

Malkki, L. (1996), Speechless Emissaries: Refugees, Humanitarianism and Dehistoricization. Cultural Anthropology, 11(3), 377-404.

Moritz, A. (2012). Supporting refugee women's strategies for coping with challenges during maternity in resettlement: Shifting the focus from vulnerability to agency. Revista Iberoamericana de Salud y Ciudadania, 1(1), 119-156.

Olivius, E. (2016). Constructing Humanitarian Selves and Refugee Others. International Feminist Journal of Politics, 18(2), 270-290. 
Peroni, L., and Timmer, A. (2013). Vulnerable groups: the promise of an emerging concept in European Human rights Convention Law. International Journal of Constitutional Law, 11(4), 1056-1085.

Pickering, S., and Cochrane, B. (2012). Irregular Border-Crossing Deaths and Gender: Where, How and Why Women Die Crossing Borders. Theoretical Criminology, 17(1), 27-48.

Refugees International (2017). "Like a Prison»: Asylum Seekers Confined to the Greek Islands. Washington: Refugees International.

Singer, D. (2014). Falling at Each Hurdle: Assessing the Credibility of Women's Asylum Claims in Europe. In E. Arbel, C. Dauvergne and J. Millbank (Eds). Gender in Refugee Law: From the Margins to the Centre (pp. 98-115). Abingdon: Routledge.

UNHCR (1991). Guidelines on the Protection of Refugee Women. Geneva: UNHCR.

UNHCR (1995). Sexual Violence against Refugees: Guidelines on Prevention and Response. Geneva: UNHCR.

UNHCR (2003). Sexual and Gender-Based Violence against Refugees, Returnees and Internally Displaced People: Guidelines for Prevention and Response. Geneva: UNHCR

UNHCR (2006). Guidelines on International Protection: The Application of Article 1A(2) of the 1951 Convention and/or 1967 Protocol Relating to the Status of Refugees to Victims of Trafficking and Persons at Risk of Being Trafficked. Geneva: UNHCR.

Ziarek, E.P. (2013). Feminist Reflections on Vulnerability: Disrespect, Obligation, Action. SubStance, 42(3): 67-84. 